\title{
INFLUENCE OF DIABETIC NEUROPATHY ON GAIT COMPLEXITY
}

\author{
INFLUÊNCIA DA NEUROPATIA DIABÉTICA NA COMPLEXIDADEDAMARCHA
}

Vanessa Raquel Metz' (iD (Physical Education Professional) Rodrigo Maciel Andrade ${ }^{2,3}$ (ID (Physical Education Professional) Adriana Machado-Lima' (ID (Nutritionist)

Alberto Carlos Amadio 4 (ID (Physical Education Professional) Júlio Cerca Serrão 4 (ID) (Physical Education Professional) Julia Maria D'Andréa Greve² (DD (Physician)

Angélica Castilho Alonso 1,2 (DD (Physical Education Professional and Physical Therapist)

1. Universidade São Judas Tadeu (USJT), Department of Aging Sciences, São Paulo, SP, Brazil. 2. Universidade de São Paulo (USP), School of Medicine, Laboratory of Movement Study, Department of Orthopedics and Traumatology, São Paulo, SP, Brazil. 3. Universidade Anhembi Morumbi, School of Health Sciences, Research, Sports and Physical Activity Group, São Paulo, SP, Brazil.

4. Universidade de São Paulo (USP), School of Physical Education and Sports, Biomechanics Laboratory, São Paulo, SP, Brazil.

\section{Correspondence:}

Angelica Castilho Alonso

R. Taquari, 546 - Mooca - São Paulo,

SP - CEP: 03166-000

e-mail: angelicacastilho@msn.com

\begin{abstract}
Introduction: Human gait is a complex movement dependent on multilevel neural control, which allows a consistent, regular and complex periodic pattern, properties that characterize it as a nonlinear system. Sensory and motor deficits, with diminished proprioceptive responses, may reduce the adaptive capacity of the system, as demonstrated in Parkinson's, Alzheimer's and Huntington's diseases. However, little is known about the effect of peripheral diabetic neuropathy on these responses. Objectives: To analyze the influence of peripheral diabetic neuropathy on entropy in different gait environments. Methods: Ten elderly patients, with and without a diagnosis of peripheral diabetic neuropathy, walked on a treadmill (initial speed of $3 \mathrm{~km} / \mathrm{h}$, with $0.5 \mathrm{~km} / \mathrm{h}$ increments every 5 minutes up to the speed of $5 \mathrm{~km} / \mathrm{h}$ ) to record center of mass acceleration in the vertical, mediolateral and anteroposterior components throughout the test. The sample entropy of the three vectors was calculated for each test speed. Results: The vertical component did not show any statistically significant differences. The mediolateral component showed statistically significant difference for the factors group, speed, and interaction between factors (group and speed). The anteroposterior component showed statistically significant differences for the group factor, but not for speed and interaction between factors (group and speed). Effect sizes classified as large were found in all the comparisons. Conclusions: Peripheral diabetic neuropathy produced changes in the ability to adapt to changes in the environment during gait, probably due to changes in the complexity of the multilevel neural control system, which depends on motor and sensory feedback, known to be affected by peripheral diabetic neuropathy. Level of Evidence Il; Diagnostic studies - Investigating a diagnostic test.
\end{abstract}

Keywords: Diabetes mellitus; Aging; Gait.

\section{RESUMO}

Introdução: A marcha humanaéum movimento complexo dependente de controle neural multinivel, que permite um padrão periódico uniforme, regular e complexo, que a caracterizam como um sistema não linear. O déficit sensitivo e motor com diminuição das respostas proprioceptivas pode diminuir a capacidade de adaptação do sistema, como já demonstrado nas doenças de Parkinson, Alzheimer e Huntington. Contudo, pouco se conhece sobre o efeito da neuropatia diabética periférica nessas respostas. Objetivos: Analisar a influência da neuropatia diabética periférica na entropia em diferentes ambientes de marcha. Métodos: Dez idosos, sem e com diagnóstico de neuropatia diabética periférica, caminharam em esteira rolante (velocidade inicial $3 \mathrm{~km} / \mathrm{h}$ e incremento de $0,5 \mathrm{~km} / \mathrm{h}$ a cada 5 minutos até a velocidade $5 \mathrm{~km} / \mathrm{h}$ ) para o registro da aceleração do centro de massa nos componentes vertical, médio-lateral, e anteroposterior ao longo de todo teste. A entropia amostral dos três vetores foi calculada para cada velocidade de teste. Resultados: O componente vertical não apresentou nenhuma diferença com significância estatística. O componente médio-lateral mostrou diferenças com significância estatística para os fatores grupo, velocidade e interação entre os fatores (grupo e velocidade). O componente anteroposterior apresentou diferenças com significância estatística para o fator grupo, mas não para o fator velocidade e interação entre os fatores (grupo e velocidade). Em todas as comparações, foram encontrados tamanhos de efeito classificados como grandes. Conclusões: A neuropatia diabética periférica produziu alterações na capacidade de adaptação sobre as variações do ambiente durante a marcha, provavelmente, em decorrência de alterações da complexidade do sistema de controle neural multinivel, que depende da retroalimentação sensitiva e motora, sabidamente afetadas pela neuropatia diabética periférica. Nível de Evidência

\section{II; Estudos diagnósticos - Investigação de um exame para diagnóstico.}

Descritores: Diabetes mellitus; Envelhecimento; Marcha.

\section{RESUMEN}

Introducción: La marcha humana es un movimiento complejo dependiente de control neural multinivel, que permite un patrón periódico uniforme, regular y complejo, que la caracterizan como un sistema no lineal. El déficit sensitivo y motor con disminución de las respuestas propioceptivas puede disminuir la capacidad de adaptación del sistema, como ya fuera demostrado en las enfermedades de Parkinson, Alzheimery Huntington. No obstante, poco se conoce sobre el efecto de la neuropatía diabética periférica en esas respuestas. Objetivos: Analizar la influencia de la neuropatía diabética periférica en la entropía en diferentes ambientes de marcha. Métodos: Diez ancianos, sin y con diagnóstico de neuropatía diabética periférica, caminaron en cinta rodante (velocidad inicial $3 \mathrm{~km} / \mathrm{h}$ e incremento de 0,5 km/h a cada 5 minutos hasta la velocidad de $5 \mathrm{~km} / \mathrm{h}$ ) para el registro de la aceleración del centro de masa 
en los componentes vertical, medio-lateral, e anteroposterior a lo largo de todo el test. La entropía de muestreo de los tres vectores fue calculada para cada velocidad de test. Resultados: El componente vertical no presentó ninguna diferencia con significancia estadística. El componente medio-lateral mostró diferencias con significancia estadística para los factores grupo, velocidad e interacción entre los factores (grupo y velocidad). El componente anteroposterior presentó diferencias con significancia estadística para el factor grupo, pero no para el factor velocidad e interacción entre los factores (grupo y velocidad). En todas las comparaciones, se encontraron tamaños de efecto clasificados como grandes. Conclusiones: La neuropatía diabética periférica produjo alteraciones en la capacidad de adaptación sobre las variaciones del ambiente durante la marcha, probablemente como consecuencia de alteraciones de la complejidad del sistema de control neural multinivel, que depende de la retroalimentación sensitiva y motora, sabidamente afectadas por la neuropatía diabética periférica. Nivel de Evidencia ll; Estudios de diagnósticos - Investigación de un examen para diagnóstico.

Descriptores: Diabetes mellitus; Envejecimiento; Marcha.

\section{INTRODUCTION}

Human locomotion can be defined as the action whereby the body moves in space, and is achieved through postural control, and dynamic motor control to adapt the projection of the center of mass (CoM) within the base of support, and the execution of fine, coordinated movements. ${ }^{1}$

It can be held that at the level of the central nervous system, a basic locomotor pattern is generated and executed under the control of the descending pathways. ${ }^{2}$ This locomotor pattern is fed back and adapted to environmental changes through information from the visual, vestibular and proprioceptive systems. Considering that the proprioceptive system, which promotes feedback about the state of the effector system and the environment, is composed of muscle, joint and skin receptors, it can be pointed out human gait requires complex and dynamic sensorimotor interactions.

Human gait is a complex movement dependent on multilevel neural control, which allows a consistent, regular and periodic pattern of kinetic, kinematic, and muscle activity variables. ${ }^{3,4}$

It is important to note that the complexity of the systems that interact to produce this movement, characterize gait as a non-constant regular and periodic consistent pattern phenomenon. ${ }^{4}$ Thus it is a non-linear system, since given the high sensitivity to initial changes in the system, and the impossibility of knowing such conditions, it is highly unpredictable in terms of response over time series. ${ }^{5}$

With this in mind, diseases characterized by sensory and motor deficits of any kind, with diminished proprioceptive responses, may reduce the system's ability to adapt to environmental changes in routine tasks, such as walking. This condition has already been demonstrated in degenerative diseases such as Parkinson's and Alzheimer's. ${ }^{6}$

In this condition, type 2 Diabetes (T2D), a disease characterized by elevated blood glucose due to a change in the secretion or action of the hormone insulin, must be taken into account, since the main complications include peripheral diabetic neuropathy (PDN), which is characterized by sensory and motor deficit besides gradual loss of sensitivity, entailing diminished proprioceptive responses.?

In such a scenario, PDN could result in impaired sensory feedback from the visual, vestibular and proprioceptive systems, and consequently bring about a decrease in the system's ability to adapt to changes in the environment.

Although the indicators of fluctuation in the gait parameters of young adults, the elderly and people with neurodegenerative diseases are already known, ${ }^{6}$ these indicators achieve their purpose through classical paradigms based on linear measures (absolute variability: amplitude and standard deviation or relative variability: coefficient of variation $)^{5}$ that fail to fulfill fundamental aspects of human movement, such as degrees of freedom, reconciliation of consistency, skilled movement variability and motor equivalence. ${ }^{8}$

In view of this condition, knowledge about the possible influence of PDN on the impairment of sensory feedback and the system's adaptability to environmental changes in daily tasks such as gait, is still based on hypothetical situations, besides using linear measurements.

Therefore, the objective of this study was to analyze the influence of PDN on the system's ability to adapt to changes in the environment during gait, using nonlinear measurement.

\section{MATERIALS AND METHODS}

This is a cross-sectional study approved by the institutional review board of Universidade São Judas Tadeu under CAAE (Ethics Evaluation Submission Certificate) no. 68816517.3.0000.0089. All the participants signed the informed consent form (ICF).

We assessed ten elderly subjects with T2D subdivided into two groups, as follows: T2D without a diagnosis of PDN (without PDN; $\mathrm{n}=5$; age: $69 \pm 4$ years; height: $1.6 \pm 0.1 \mathrm{~m}$; body mass: $78.1 \pm 8.4 \mathrm{~kg}$; $\mathrm{BMI}=29.6 \pm 3.2 \mathrm{~kg} / \mathrm{m}^{2}$ ), and T2D with a diagnosis of PDN (with PDN; $\mathrm{n}=5$; age: $72 \pm 4$ years; height: $1.8 \pm 0.1 \mathrm{~m}$; body mass: $88.0 \pm 19.9 \mathrm{~kg}$; $\left.\mathrm{BMI}=28.4 \pm 6.1 \mathrm{~kg} / \mathrm{m}^{2}\right)$.

The inclusion criteria were: male subjects with T2D for more than 5 years, aged between 60 to 79 years, functional independence, absence of disease or functional impairment of the auditory, vestibular, proprioceptive, neurological and mental systems, and not having undergone any kind of orthopedic surgery. All conditions were identified by medical assessment. Exclusion criteria were discomfort or inability to walk on a treadmill for 30 minutes.

\section{Assessments}

The subjects were initially presented with a questionnaire containing demographic data, then underwent the following anthropometric assessments: body mass and height, followed by calculation of Body Mass Index (BMI). ${ }^{9}$

To identify PDN, changes in sensitivity to mechanical stimulus were assessed using esthesiometry. Test specimen contact in different thermal conditions was used for thermal stimulus and tuning fork contact, as recommended by the literature, for vibratory stimulus. ${ }^{10}$

The volunteers then underwent the gait test on a computerized treadmill, model KT 10200 (Inbramed ${ }^{\oplus}$, Porto Alegre, Rio Grande do Sul, Brazil), in order to quantify the parameters related to the CoM acceleration time series. An initial speed of $3.0 \mathrm{~km} / \mathrm{h}$ was adopted, with increments of $0.5 \mathrm{~km} / \mathrm{h}$ in the treadmill speed every 5 minutes, until the 
volunteer could no longer keep up the gait but had to start running, or was required to submit a self-report of inability to continue the test.

The CoM acceleration time series was quantified by means of an isoinertial (ISO) sensor, positioned over the sacrum ${ }^{11}$ and fixed by an elastic bandage wrapped around the circumference of the subject's hip. ${ }^{12}$ We used an isoinertial (ISO) sensor composed of a programmable Arduino ${ }^{\oplus}$ GENUINO $101^{\oplus}$ board with a dual-core Intel ${ }^{\circledR}$ Curie $^{\mathrm{TM}}$ module, 384 KB flash memory, an accelerometer and 6-axis gyroscope.

The CoM acceleration time series were acquired in the vertical (acelV), mediolateral (acelML) and anteroposterior (acelAP) components, at a sampling frequency of $294 \mathrm{~Hz}$.

The programming for operation of the ISO was written in algorithm (sketch) via Integrated Development Environment (IDE) version 1.8.1 for MacBook ${ }^{\circledast}$, language software based on $\mathrm{C} / \mathrm{C}++$, and developed specifically by Arduíno:

Moreover, aiming to minimize potential influences of the treadmill familiarization process, subjects initially underwent a 10-minute walking session at $3.0 \mathrm{~km} / \mathrm{h}$ using the same test treadmill and equipment, before the measurement acquisition procedures.

Once determined, acelV, acelML and acelAP were exported to the Matrix Laboratory ${ }^{\circledast}\left(\right.$ MATLAB $\left.^{\circledR}\right)$ environment [MathWorks Inc., Natick, USA, version R20016a for Mac@], where we then estimated the statistical parameter of nonlinear dynamical system sample entropy (SampEn) for acelV, acelML and acelAP (SampEn_acelV,SampEn_acel$M L$ and SampEn_acelAP, respectively) at each speed (5-minute stage) of the treadmill test (SampEn_acelV_3.0, SampEn_acelV_3.5, SampEn_acelV_4.0), assuming that these were complexity indicators. ${ }^{13}$ The parameters embedding dimension $=2$ and tolerance employed= 0.2 were used in all the analyses.

\section{Statistical analysis}

Normality and homoscedasticity were checked using the Shapiro-Wilk and Levene test. ${ }^{14}$ We applied the repeated measures ANOVA (analysis of variance) test (General Linear Model [GLM]) to analyze the entropy values of each stage and over the total test period. The Bonferroni post-hoc test was used when necessary. ${ }^{15}$

Considering that significance tests are dependent on sample size, and that in small samples, findings without statistical significance may be of practical relevance, ${ }^{16}$ the partial Eta-squared statistic $\left(\eta^{2}\right)^{17}$ was quantified, and values up to 0.059 were classified as small effect size, those between 0.059 and 0.138 as medium size effect, and those above 0.138 as large size effect. ${ }^{17}$

The level of significance adopted was 5\%. All the parameters were obtained using IBM ${ }^{@}$ SPSS ${ }^{\circledR}$ Statistics software in version 24.0 for Mac (SPSS Inc., Chicago, IL, USA).

\section{RESULTS}

The descriptive values of the parameters obtained are presented in Table 1.

In the acceleration time series analysis in the vertical component, we found evidence of differences without statistical significance for the factors group $\left[F(1.4)=2.566, p=0.184, \eta^{2}=0.391\right.$, power $\left.=0.236\right]$, speed $\left[F(4.16)=1.107, p=0.387, \eta^{2}=0.217\right.$, power $\left.=0.27\right]$, and interaction between group ${ }^{*}$ speed factors $\left[F(3,47.16)=1.2, p=0.352, \eta^{2}=0.231\right.$, power $=0.222]$. However, large effect sizes were found in all the comparisons.

For the mediolateral component, significant differences were found for the factors group $\left[F(1.4)=10.692, p=0.031, \eta^{2}=0.728\right.$, power $=0.690]$, speed $\left[F(4.16)=3.433, p=0.036, \eta^{2}=0.455\right.$, power $\left.=0.716\right]$, and interaction between group ${ }^{*}$ speed factors $[F(4.16)=3.726, p=0.025$, $\eta^{2}=0.482$, power $\left.=0.494\right]$, as well as large effect sizes.
For the anteroposterior component, significant differences were found for the group factor $\left[F(1.4)=9.60, p=0.036, \eta^{2}=0.709\right.$, power $=0.646]$, but without statistical differences for speed $[F(4.16)=$ 2.967, $p=0.052, \eta^{2}=0.426$, power $\left.=0.657\right]$ and interaction between group*speed factors $\left[F(4.16)=1.446, p=0.295, \eta^{2}=0.266\right.$, power $\left.=0.155\right]$, with large effect sizes. There were differences in entropy between the groups with (0.284) and without $(0.478, p=0.031)$ PDN, and between the speeds $3.5 \mathrm{~km} / \mathrm{h}$ (SampEn_acelML_3.5=0.439) and $5 \mathrm{~km} / \mathrm{h}$ (SampEn_acelML_5.0 $=0.308, p=0.036$ ) (Figure 1).

Regarding interaction between the group*speed factors, differences were found in the group with PDN at speeds of $4 \mathrm{~km} / \mathrm{h}$ (SampEn_acelML_4.0 =0.203), $4.5 \mathrm{~km} / \mathrm{h}$ (SampEn_acelML_4.5 = 0.157), and $5 \mathrm{~km} / \mathrm{h}\left(S a m p E n \_a c e I M L \_5.0=0.160\right)$ compared to the group without PDN [4 km/h (SampEn_acelML_4.0 $=0.275, \mathrm{p}=0.013), 4.5 \mathrm{~km} / \mathrm{h}$ (SampEn_acelML_4.5 $=0.281, p=0.004)$ and $5 \mathrm{~km} / \mathrm{h}$ (SampEn_acelML_5.0 $=0.268, p=0.018)$ ] (Figure 2).

In the anteroposterior component, significant differences were found in the group factor $\left[F(1.4)=9.606, p=0.036, \eta^{2}=0.706\right.$, power $\left.=0.646\right]$, but not for the speed factor $\left[F(4.16)=2.967, p<0.052, \eta^{2}=0.426\right.$, power $=0.657]$ and interaction between the group ${ }^{*}$ speed factors $[F(2,105,16)$ $=1.071, p<0.389, \eta^{2}=0.211$, power $\left.=0.182\right]$. The observed effect sizes were classified as large. There were differences in entropy between the groups with (0.259) and without $(0.308, p=0.036)$ PDN (Figure 1).

Table 1. Mean and standard deviation of the nonlinear dynamical system sample entropy (SampEn) of the groups with and without peripheral diabetic neuropathy with speed increments.

\begin{tabular}{c|c|c|c|c|c|c|c}
\hline & & \multicolumn{2}{c|}{ SampEn_acelV } & \multicolumn{2}{c|}{ SampEn_acelML } & \multicolumn{2}{c}{ SampEn_acelAP } \\
\hline \multirow{2}{*}{ Group } & Speed & Mean & SD & Mean & SD & Mean & SD \\
\hline \multirow{5}{*}{ With PDN } & $3.0 \mathrm{~km} / \mathrm{h}$ & 0.205 & 0.118 & 0.407 & 0.166 & 0.326 & 0.026 \\
\cline { 2 - 9 } & $3.5 \mathrm{~km} / \mathrm{h}$ & 0.214 & 0.114 & 0.344 & 0.243 & 0.328 & 0.056 \\
\cline { 2 - 9 } & $4.0 \mathrm{~km} / \mathrm{h}$ & 0.203 & 0.121 & 0.261 & 0.097 & 0.248 & 0.065 \\
\cline { 2 - 9 } & $4.5 \mathrm{~km} / \mathrm{h}$ & 0.157 & 0.080 & 0.209 & 0.090 & 0.217 & 0.002 \\
\cline { 2 - 9 } & $5.0 \mathrm{~km} / \mathrm{h}$ & 0.160 & 0.069 & 0.200 & 0.072 & 0.174 & 0.049 \\
\hline \multirow{5}{*}{ Without PDN } & $3.0 \mathrm{~km} / \mathrm{h}$ & 0.256 & 0.034 & 0.472 & 0.057 & 0.346 & 0.089 \\
\cline { 2 - 9 } & $3.5 \mathrm{~km} / \mathrm{h}$ & 0.283 & 0.067 & 0.464 & 0.047 & 0.312 & 0.050 \\
\cline { 2 - 8 } & $4.0 \mathrm{~km} / \mathrm{h}$ & 0.275 & 0.037 & 0.505 & 0.051 & 0.307 & 0.017 \\
\cline { 2 - 8 } & $4.5 \mathrm{~km} / \mathrm{h}$ & 0.281 & 0.052 & 0.533 & 0.053 & 0.279 & 0.052 \\
\cline { 2 - 8 } & $5.0 \mathrm{~km} / \mathrm{h}$ & 0.268 & 0.053 & 0.415 & 0.061 & 0.298 & 0.059 \\
\hline
\end{tabular}

Key: nonlinear dynamical system sample entropy (SampEn); CoM acceleration in the vertical (acelV), mediolateral (acelML) and anteroposterior (acelAP) components; sd - standard deviation; PDN - peripheral diabetic neuropathy

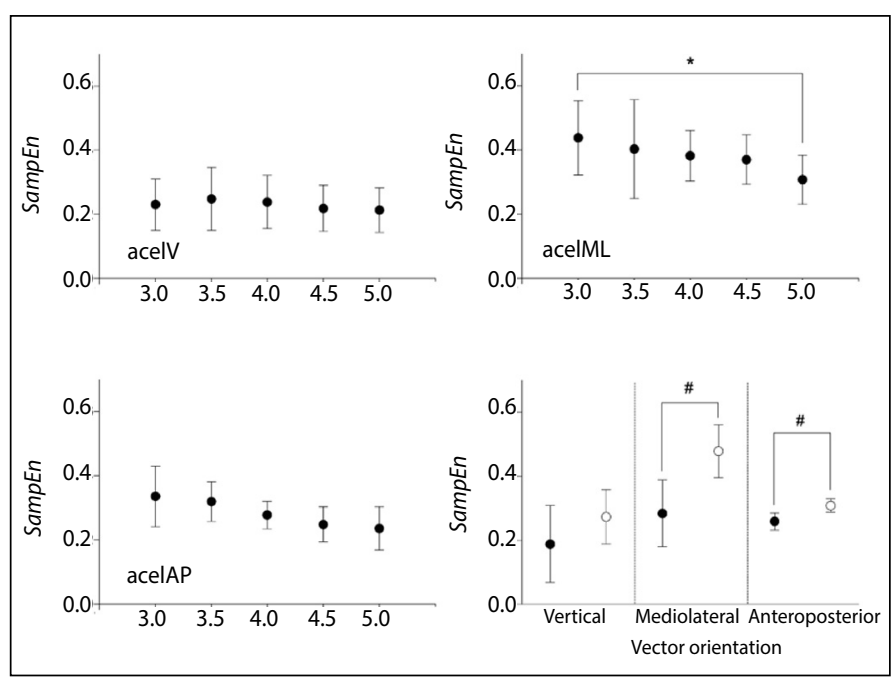

Figure 1. Graphical representation of sample entropy (SampEn) values, considering the speed factor of the center of mass acceleration time series in the vertical (acelV), mediolateral (acelML) and anteroposterior (acelAP) components, and the group factor of the same time series. 


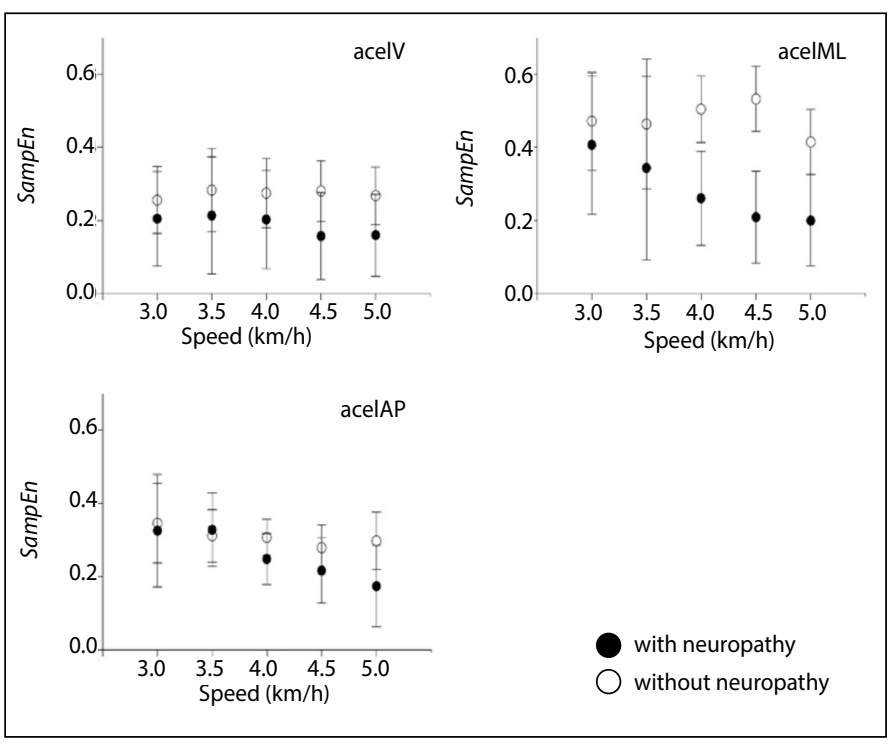

Figure 2. Graphical representation of sample entropy (SampEn) values, considering the interaction of the speed and group factors, of the center of mass acceleration time series in the vertical (acelV), mediolateral (acelML) and anteroposterior (acelAP) components.

\section{DISCUSSION}

The findings of the study show that elderly people with PDN had decreased entropy values in the mediolateral vector concomitantly with an increase in gait speed. Accordingly, it can be said that PDN influenced entropy from CoM displacement in the mediolateral and anteroposterior vectors, but not in the vertical vector, which is consistent with the literature where changes related to PDN lead to functional adaptations of gait, such as lower self-selected and maximum speed, shorter strides, and higher cadence. ${ }^{18}$ Considering that PDN is characterized by sensory and motor deficit, ${ }^{7}$ a decrease in the system's ability to adapt to changes in the environment in routine tasks has been pinpointed as a possible explanation for changes in gait.

Given that SampEn is conceptually indicative of complexity, informing the adaptability of a system to changes in the environment, a system with restricted adaptability to changes in the environment generally has a regular behavior with low entropy value. This phenomenon is the opposite of that found in a system without adaptation restrictions. ${ }^{18}$

In the gait cycle, CoM displacement can be represented as an inverted pendulum with a sine wave. ${ }^{19}$ Thus, the highest entropy values found in subjects with PDN reflect a greater variability in CoM displacement, thus signaling an irregular system. ${ }^{18}$

The statistically higher values of entropy reflect greater disturbance in CoM displacement in diabetics with PDN in the anteroposterior and mediolateral vectors, but not in the vertical vector. These differences merit attention, because both the increase in $\mathrm{CoM}^{20}$ displacement and the decrease/absence of $\mathrm{CoM}^{20,21}$ displacement increase the metabolic cost of walking (CoW).

It is worth remembering that the sine wave is representative of the principle of conservation of mechanical energy ${ }^{22}$ and the cost of walking (CoW). ${ }^{18}$ The elevation and negative acceleration in the sine wave of CoM displacement found in the first half of the gait cycle support phase ${ }^{19}$ is characterized by conversion of kinetic energy into gravitational potential, ${ }^{23}$ whereas depression and positive acceleration in the second half of the support phase ${ }^{19}$ are characterized by a conversion of gravitational potential energy into kinetic energy. ${ }^{23}$ Therefore, an ideal CoM displacement must be produced in terms of its effect on the CoW, and deviations from this ideal indicate inefficiency in terms of energetic cost, which is consistent with the scenario expected in PDN.

However, the increased CoW is caused instead by the additional work undertaken to reorganize CoM oscillations during step-by-step transitions, as well as by the work needed to restore the lost energy. ${ }^{18}$ Although in mechanical terms such an adjustment is multifaceted, the increased CoW is due to a complex interaction of sensory (impaired vibration and protective sensation), muscle and joint impairment (mobility), ${ }_{1}^{24}$ which result in kinetic, EMG and kinematic changes. . $^{24,25}$

For example, the debility characteristic of PDN would produce less incursion of the knee joints during the support phase, changing the stride length, and this would consequently cause greater disturbance in the fluctuation of CoM displacement and the CoW. ${ }^{18}$

An increase in calcaneal tendon stiffness resulting in a reduction in ankle range of motion has been pinpointed in subjects with PDN. ${ }^{26}$ This would ultimately change both gait dynamics and CoM displacement; moreover, it would reduce the generation and restitution of elastic energy during gait, requiring a greater contribution from the contractile components of the plantar region, thereby increasing muscle work and CoW. ${ }^{27}$

However, changes in gait are also associated with other diabetic complications 2 such as impaired visual acuity and balance, ${ }^{28}$ which compromise space-time organization, positioning and control of lower limb movement. ${ }^{29}$ This would have an impact on postural stability and be a possible source of explanation for the greater disturbance in the fluctuation of CoM displacement and CoW in a subject with PDN.

This condition also indicates that subjects with PDN can develop gait dysfunctions and abnormalities even before sensory impairment in the feet, given the systemic sensory impairment produced by the disease.

In summary, elderly patients with PDN have greater variability in CoM displacement in the anteroposterior and mediolateral vectors, leading to an increase in the CoW. In view of all the possible impairments linked to PDN, they adopt a more conservative gait pattern as an adaptive compensatory mechanism for the established disease. ${ }^{30}$ However, this change is not only due to the reduction of sensory information available to the local peripheral system and by extension to the central nervous system, but also due to the growing demands for attention needed to control and regulate gait complexity. ${ }^{30}$

\section{CONCLUSIONS}

Peripheral diabetic neuropathy produced changes in the sensorimotor adaptability to respond to changes in the environment experienced during gait.

We could consider the possibility of this response being representative of changes in the complexity of the multilevel neural control system, which is dependent on sensory and motor feedback, affected by peripheral diabetic neuropathy.

\section{ACKNOWLEDGMENTS}

This study was carried out with the support of the Coordenação de Aperfeiçoamento de Pessoal de Nível Superior - Brazil (CAPES) (High-Tier Personnel Upskilling Coordination Office), under funding code 001.

This Study was partly funded by the Coordenação de Aperfeiçoamento de Pessoal de Nível Superior - Brazil (CAPES) (High-Tier Personnel Upskilling Coordination Office), under funding code 001.

All authors declare no potential conflict of interest related to this article 
AUTHORS' CONTRIBUTIONS: Each author made significant individual contributions to this manuscript. VRM: data collection, writing, preparation of the entire research project; RMA: data collection and analysis, writing and preparation of the entire research project; ACA: review and intellectual concept; JCS and JMDAG: writing, review and intellectual concept; AML and ACA: writing, intellectual concept and preparation of the entire research project. All authors approved the final version of the article.

\section{REFERENCES}

1. Winter DA, Patla AE, Frank JS. Assessment of balance control in humans. Med Prog Technol. 1990;16(1-2):31-51.

2. Rossignol S, Dubuc R, Gossard JP. Dynamic sensorimotor interactions in locomotion. Physiol Rev. 2006;86(1):89-154

3. Terrier $P$, Deriaz $O$. Persistent and anti-persistent pattern in stride-to-stride variability of treadmill walking: influence of rhythmic auditory cueing. Human Mov Sci. 2012;31(6):1585-97.

4. Hausdorff JM, Ashkenazy Y, Peng CK, Ivanov PC, Stanley HE, Goldberger AL. When human walking becomes random walking: fractal analysis and modeling of gait rhythm fluctuations. Physica A. 2001:302(1-4):138-47.

5. Stergiou N. Innovative Analyses of human movement. Champaign, IL: Human Kinetics; 2004

6. Beauchet $\mathrm{O}$, Annweiler C, Lecordroch Y, Allali G, Dubost V, Herrmann FR, et al. Walking speed-related changes in stride time variability: effects of decreased speed. J Neuroeng Rehabil. 2009;6:32

7. Bacarin TA, Sacco IC, Hennig EM. Plantar pressure distribution patterns during gait in diabetic neuropathy patients with a history of foot ulcers. Clinics (Sao Paulo). 2009;64(2):113-20.

8. Tani G. Aprendizagem motora: tendéncias, perspectivas e problemas de investigação. Rev Galego-Portuguesa Psicoloxía Educ. 1998;2(2):199-215.

9. Norton K, Whittingham N, Carter L, Kerr D, Gore C, Marfell-Jones M. Técnicas de medição em antropometria. In: Norton K, Olds T, eds. Albernaz NMFd, trans. Antropométrica. Porto Alegre: Artmed; 2005:41-87.

10. Nery CA, Alloza JF, Batista F. Sensibilidade térmica cutânea: estudo comparativo entre dois métodos de mensuração e proposta de simplificação. Rev Bras Ortop. 2000;35(9):358-63.

11. Saini M, Kerrigan DC, Thirunarayan MA, Duff-Raffaele M. The vertical displacement of the center of mass during walking: a comparison of four measurement methods. J Biomech Eng. 1998;120(1):133-9

12. Lee JB, Sutter KJ, Askew CD, Burkett BJ. Identifying symmetry in running gait using a single inertial sensor. J Sci Med Sport. 2010;13(5):559-63.

13. Gao J, Hu J, Liu F, Cao Y. Multiscale entropy analysis of biological signals: a fundamental bi-scaling law. Front Comput Neurosci. 2015;9:64.

14. Hair JF, BlackWC, Babin BJ, Anderson RE. Multivariate data analysis. 7th ed. Bergen County; New Jersey: Prentice Hall; 2009.

15. Kim HY. Statistical notes for clinical researchers: assessing normal distribution (2) using skewness and kurtosis. Restor Dent Endod. 2013;38(1):52-4.

16. Levine TR, Hullett CR. Eta squared, partial eta squared, and misreporting of effect size in communication research. H Com Res. 2006;28(4):612-25.
17. Kotrlik JW, Williams HA. The incorporation of effect size in information technology, learning, and performance research. Inf Techn Learning Perf J. 2003;9(3):34-43.

18. Petrovic M, Maganaris CN, Bowling FL, Boulton AJM, Reeves ND. Vertical displacement of the centre of mass during walking in people with diabetes and diabetic neuropathy does not explain their higher metabolic cost of walking. J Biomech. 2019;83:85-90.

19. Candrilli SD, Davis KL, Kan HJ, Lucero MA, Rousculp MD. Prevalence and the associated burden of illness of symptoms of diabetic peripheral neuropathy and diabetic retinopathy. J Diabetes Complications. 2007;21(5):306-14

20. Massaad F, Lejeune TM, Detrembleur C. The up and down bobbing of human walking: a compromise between muscle work and efficiency. J Physiol. 2007;582(Pt 2):789-99.

21. Gordon KE, Ferris DP, Kuo AD. Metabolic and mechanical energy costs of reducing vertical center of mass movement during gait. Arch Phys Med Rehabil. 2009;90(1):136-44.

22. Alexander RM. Energy-saving mechanisms in walking and running. J Exp Biol. 1991;160:55-69.

23. Cavagna GA, Franzetti P. The determinants of the step frequency in walking in humans. J Physiol. 1986;373:235-42

24. Sacco IC, Hamamoto AN, Onodera AN, Gomes AA, Weiderpass HA, Pachi CG, et al. Motor strategy patterns study of diabetic neuropathic individuals while walking. A wavelet approach. J Biomech 2014;47(10):2475-82.

25. Sawacha Z, Guarneri G, Cristoferi G, Guiotto A, Avogaro A, Cobelli C. Integrated kinematics-kinetics-plantar pressure data analysis: a useful tool for characterizing diabetic foot biomechanics. Gait Posture. 2012;36(1):20-26

26. Petrovic M, Maganaris CN, Deschamps K, Verschueren SM, Bowling FL, Boulton AJ, et al. Altered Achilles tendon function during walking in people with diabetic neuropathy: implications for metabolic energy saving. J Appl Physiol (1985). 2018;124(5):1333-40.

27. Cronin NJ, Peltonen J, Ishikawa M, Komi PV, Avela J, SinkjaerT, et al. Achilles tendon length changes during walking in long-term diabetes patients. Clin Biomech (Bristol, Avon). 2010;25(5):476-82.

28. Courtemanche R, Teasdale N, Boucher P, Fleury M, Lajoie Y, Bard C. Gait problems in diabetic neuropathic patients. Arch Phys Med Rehabil. 1996;77(9):849-55.

29. Lamola G, Venturi M, Martelli D, lacopi E, Fanciullacci C, Coppelli A, et al. Quantitative assessment of early biomechanical modifications in diabetic foot patients: the role of foot kinematics and step width. J Neuroeng Rehabil. 2015;12:98.

30. Ko M, Hughes L, Lewis H. Walking speed and peak plantar pressure distribution during barefoot walking in persons with diabetes. Physiother Res Int. 2012;17(1):29-35. 